\title{
Integration of formal and informal sector (waste bank) in waste management system in Yogyakarta, Indonesia
}

\author{
Hijrah Purnama Putra ${ }^{1, *}$,Enri Damanhuri ${ }^{2}$, and Emenda Sembiring ${ }^{2}$ \\ ${ }^{1}$ Department of Environmental Engineering, FTSP Universitas Islam Indonesia, Jalan Kaliurang km 14,5 Sleman, Yogyakarta 55584, \\ Indonesia \\ Doctoral Student in Environmental Engineering Department, FTSL, Institut Teknologi Bandung \\ ${ }^{2}$ Department of Environmental Engineering, FTSL Institut Teknologi Bandung, Jalan Ganesa 10, Bandung 40132, Indonesia
}

\begin{abstract}
The change of waste management paradigm becomes an important thing to do, as a step adaptation to the increasing rate of waste generation every year in Indonesia. $100 \%$ management target has been divided into two parts, namely the reduction (30\%) and waste handling (70\%). Reductions focus on source limitation and $3 \mathrm{R}$ program optimization, whereas handling involves collecting and final processing activities. However, the current level of waste reduction is still very low $(12 \%)$, the government made various efforts to increase it, one of its with the waste bank program. DIY province as a pioneer in the concept of waste bank continues to develop to increase the participation of the community, from 166 locations in 2013, increased to 792 locations in 2017 and 495 of its as the waste bank (62.5\%). Average waste bank with 43 customers, able to manage the waste up to $2,078,064 \mathrm{~kg} / \mathrm{month}$, with the data can be estimated the amount of waste that can be managed in the city of Yogyakarta, Sleman and Bantul Regency. The city of Yogyakarta has 433 units of the waste bank, capable of managing waste up to $899,801.8 \mathrm{~kg} / \mathrm{month}$, Sleman Regency has 34 units of the waste bank (78.966,4 kg/month) and Bantul has 24 units of the waste bank (49.873,5 kg/month ). The integration of formal and informal sectors through waste banks can increase the percentage of waste management services. The level of service in Yogyakarta City increased from $85 \%$ to $95.5 \%$, Sleman District from 30.71 to $31 \%$, and Bantul Regency from 7.49 to $7.7 \%$
\end{abstract}

\section{Introduction}

The enactment of Law 18/2008 on Waste Management, a turning point in Indonesia's waste management system, returns waste into a resource that must be managed to minimize negative impacts on the environment. Changes in the concept of waste management from CollectTransport-Dispose to Collect-Transport-Manage accompanied by minimization on waste generation, sorting, reuse, and recycling or known as the $3 \mathrm{R}$ program (Reduce, Reuse and Recycle) through intelligent, efficient and programmed [1].

Based on the 2008 waste statistics, Indonesia has a waste generation rate of 38.5 million tons/year [2], this condition continues to increase until 2017, the waste generation has reached 65.8 million tons/year and is projected by 2025 to 71.3 million tons/year [3]. The waste management target is divided into 2 (two) major sections, namely, waste reduction and handling. Reduction through various activities of source limitation and the $3 \mathrm{R}$ program optimization, while handling is the activity of service of collecting, transporting to final processing done by the related institution, generally service area is in the urban area. Both must be consistent in order to achieve $100 \%$ service target by 2025 , reaching $30 \%( \pm 21$ million tons/year) through reduction activities and 70\% $( \pm 50$ million tons/year) through handling activities.

The level of waste reduction in 2017 is still below $12 \%$ (7.82 million tons/year) that can be handled, while handling activities reaches $71 \%$ ( 46 million tons/year), the rest is still not handled and even handled by the community in a way that not environmentally friendly, through dumping, open burning, throw in the river, even ending up in the sea [4]. The main obstacle in increasing the level of waste reduction in the source is the mindset of the community to waste, especially in the understanding and low level of awareness in the sorting. Though the key to successful waste management at the source is sorting [5]. Disaggregated waste will have a higher value, both the selling value and the value of processing.

In order to change people's mindset about waste, the Ministry of the Environment implements various strategies to improve the community's role in the $3 \mathrm{R}$ program. One of its programs is the Waste Bank, a strategy to convert waste into financial benefits for the communities involved. Based on data in February 2012 the number of waste banks in Indonesia reached 471 units with 47,125 customers and the amount of waste can be managed to reach $755,600 \mathrm{~kg} /$ month or equivalent to $\$$ $174,000 /$ month. This number continues to increase, for example, within 3 months later then the number of waste

\footnotetext{
* Corresponding author: hijrah@uii.ac.id
} 
bank reaches 886 units, with 84,623 customers and $2,001,788 \mathrm{~kg}$ of waste/month and potentially generate $\$$ $283,000 /$ month $[1,6]$. Currently, Indonesia already has 4,820 units of waste banks spread in 30 provinces and 206 districts/cities [3].

Special Province of Yogyakarta (DIY) as a province of initiator in the concept of waste bank, precisely by $\mathrm{Mr}$. Bambang Suwerda through Environmental Health Workshop which pioneered in the middle of 2006, now becomes "Gemah Ripah" Waste Bank, Bantul Regency of DIY Province continues to grow to increase the role of communities are involved in the management of waste banks

DIY Province has the potential to produce waste about $11,996 \mathrm{~m}^{3} /$ day or 2,953 tons/day (SNI 19-3983-1995, standard $3.25 \mathrm{~L} /$ person/day or equivalent to 0.8 $\mathrm{kg} /$ person/day) [7]. The potential of this waste is influenced by the population, DIY Province has more than 3.6 million people, with the spread of population dominated in Sleman Regency of $31.78 \%$, Bantul Regency $26.58 \%$, and the rest spread evenly in three other areas. The highest population density is owned by the City of Yogyakarta, which reached 12,699 people $/ \mathrm{km}^{2}$, and the lowest is Gunungkidul Regency 482 people $/ \mathrm{km}^{2}$ [8]. The level of waste service in DIY Province varies greatly between districts and other districts (Figure 1). This significant difference is caused by a system that is not always able to reach the whole region, minimal funding allocation, less professional management, limited infrastructure and human resources and access difficulties become the main obstacle [9-13].

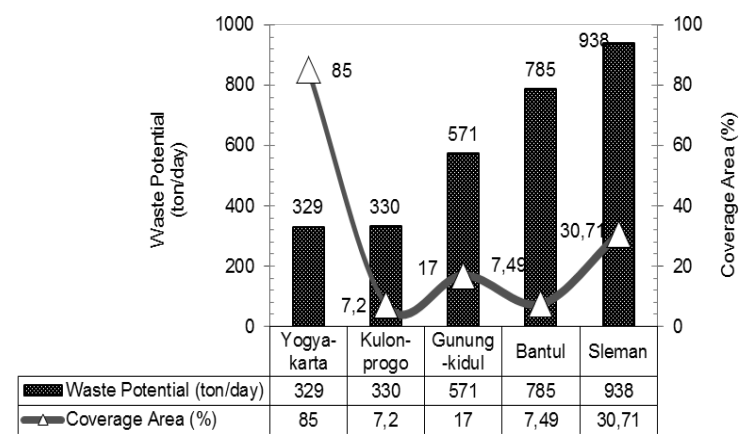

Fig. 1. Amount of waste and percentage of urban waste service (Source: Modify data from $[14,15,4]$ ).

The imbalance between the quantity of waste generated by the service capability raises the community's initiative to conduct waste management independently. From 2003 to 2011 in Yogyakarta Province, 117 groups of independent waste managers have been established [16], this data has increased to 155 groups by 2015 [17], the various groups are able to reduce waste up to $70 \%$ [18].

The role of the sector is so large (informal), but not yet considered in the planning of urban waste management system [19-21]. Strategic and comprehensive integration between the formal and the informal sectors is required, although it is a challenge in many developing countries $[21,22,13]$.

This study aims to identify informal sector activities (garbage bank), among others, in Yogyakarta, the ability of garbage banks to accept waste and increasing percentage of waste management services in Yogyakarta.

\section{Research Methodology}

This research was conducted in several phases, starting with secondary data searching the number and location of the waste bank as representative of the informal sector in DIY Province, but limited only to Yogyakarta City, Sleman and Bantul Regency. Based on the results of data collection, the waste bank of Yogyakarta City has had a recapitulation of the number of customers and waste collected. Based on the data, projected number of customers and waste can be managed in 2 (two) other regencies. The amount of waste that can be managed is linked to the potential waste generated and the waste that is transported to the landfill in order to determine the percentage of integrated waste management services to the community.

The data required in this study are as follows:

a. The number of waste banks in the 3 research areas (Yogyakarta city, Sleman and Bantul regency);

b. The number of customers of each waste bank;

c. Total type of waste that can be received by the waste bank

The data is linked to garbage entering the landfill each month, with the level of service that has been owned by each region. So it can be known the contribution of waste banks reduce waste into landfills.

\section{Results and Discussion}

Waste Bank is a sorting and collection area for recyclable/reusable waste that has economic value and is one of the $3 \mathrm{R}$ (reduce, reuse and recycle) waste management strategies in community-level waste management. Economic value becomes the trigger of active participation from the community to join in the program. Before discussing further waste bank, the following is the development of community participation through various locations of community-based waste management in the study area.

Community-based solid waste management in the study area until 2017 amounted to 792 units, of which 495 units have status as the waste bank (62.5\%) (Fig. 2). Technically the construction, operation, and management of waste banks are regulated in the Minister of Environment Regulation No. 13/2012, although the reality in the field of minimum requirements in this regulation has not been fulfilled. The distribution of waste bank in Yogyakarta City is quite evenly distributed, all districts have the waste bank. Umbulharjo district has 77 units of the waste bank and is the highest district of the number of waste banks owned, while the lowest is 13 waste banks owned by Gedongtengen district (Fig. 3). 


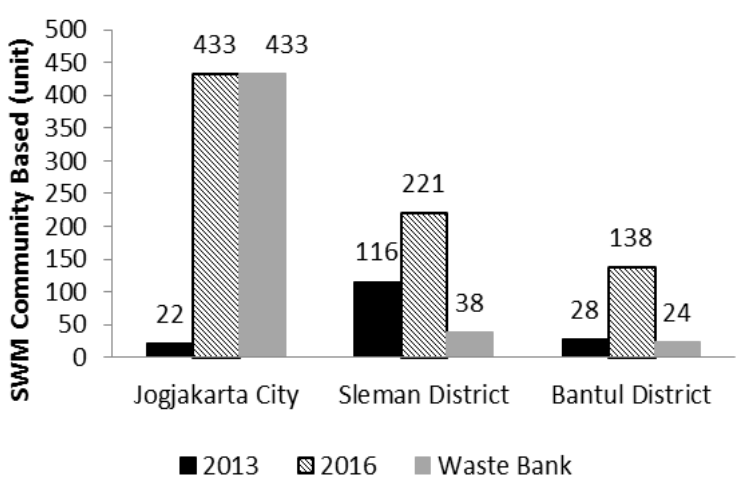

Fig. 2. Development of community-based waste management in the study area

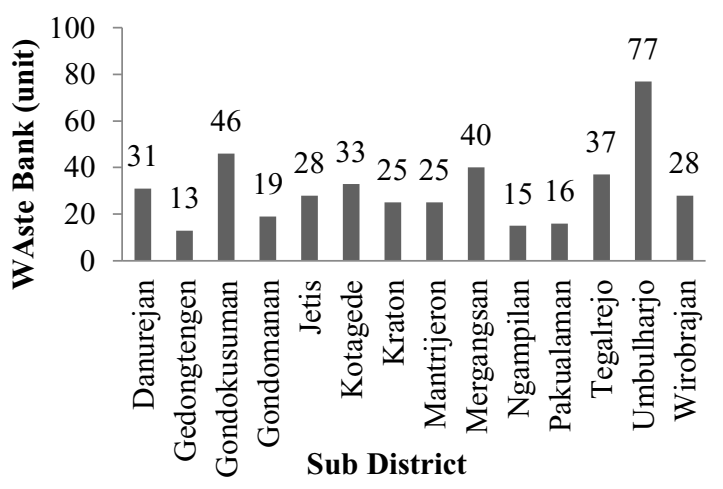

Fig. 3. Distribution of waste banks in Yogyakarta City

As for the other two regions, Sleman and Bantul regencies have districts that do not have a waste bank and in terms of numbers, the city of Yogyakarta has a larger number of waste banks. There are several factors that influence it, the main is the limited access to buyers of waste (collectors) because of the distance, in addition to the extent of the land owned yard, still allows people to burn or bury the waste because it is considered more practical without sorting.

Actually how the role of waste banks in reducing the amount of waste that goes into the formal system (urban service) or the amount of waste managed not environmentally friendly. The waste bank becomes a collection point for the communities involved, although not all waste generated is acceptable. In general, waste banks can receive paper, plastic, glass, metal and some other types of waste. However, there is also a waste bank that is more creative in sorting out different types of paper and plastic so as to obtain different types of paper and plastic. With 433 units of waste bank owned by Yogyakarta City, has managed to manage the waste worth recycling as much as $899,801,8 \mathrm{~kg} /$ month. There is the recapitulation of waste bank management in Yogyakarta City (Table 1):
Table 1. Recapitulation of waste-based on waste bank management in Yogyakarta City

\begin{tabular}{|c|c|c|c|}
\hline No & \multicolumn{2}{|c|}{ Specification } & Value \\
\hline \multirow[t]{3}{*}{1} & \multicolumn{3}{|c|}{ Customers } \\
\hline & \multicolumn{2}{|c|}{$\begin{array}{l}\text { a. Number of customers } \\
433 \text { units waste bank }\end{array}$} & 18.434 customers \\
\hline & \multicolumn{2}{|c|}{$\begin{array}{l}\text { b. Average customers per } \\
\text { a waste bank }\end{array}$} & 43 custumers/waste bank \\
\hline \multirow[t]{13}{*}{2} & \multicolumn{3}{|c|}{ The amount of waste by type } \\
\hline & \multirow[t]{2}{*}{ a. Plastic } & \multicolumn{2}{|c|}{$417.088,9 \mathrm{~kg} /$ month } \\
\hline & & \multicolumn{2}{|c|}{$963,254 \mathrm{~kg} / \mathrm{month} /$ waste bank } \\
\hline & \multirow[t]{2}{*}{ b. Paper } & \multicolumn{2}{|c|}{$465.860,7 \mathrm{~kg} / \mathrm{month}$} \\
\hline & & \multicolumn{2}{|c|}{$1.075,891 \mathrm{~kg} / \mathrm{month} /$ waste bank } \\
\hline & \multirow[t]{2}{*}{ c. Glass } & \multicolumn{2}{|c|}{$8.989,8 \mathrm{~kg} / \mathrm{month}$} \\
\hline & & \multicolumn{2}{|c|}{$20,762 \mathrm{~kg} / \mathrm{month} /$ waste bank } \\
\hline & \multirow[t]{2}{*}{ d. Metal } & \multicolumn{2}{|c|}{$5.601,9 \mathrm{~kg} / \mathrm{month}$} \\
\hline & & \multicolumn{2}{|c|}{$12,937 \mathrm{~kg} / \mathrm{month} /$ waste bank } \\
\hline & \multirow[t]{2}{*}{ e. Others } & \multicolumn{2}{|c|}{$2.260,7 \mathrm{~kg} / \mathrm{month}$} \\
\hline & & \multicolumn{2}{|c|}{$5,221 \mathrm{~kg} / \mathrm{month} /$ waste bank } \\
\hline & \multirow[t]{2}{*}{ d. Total } & \multicolumn{2}{|c|}{$899.801,8 \mathrm{~kg} / \mathrm{month}$} \\
\hline & & \multicolumn{2}{|c|}{$2.078,064 \mathrm{~kg} / \mathrm{month} /$ waste bank } \\
\hline
\end{tabular}

The average amount of waste that can be managed reaches 2,078,064 kg/month per waste bank, without considering other factors, with the data can be projected the amount of waste that can be received by waste banks in Sleman and Bantul Regency. With 34 waste bank units in Sleman Regency and 24 units in Bantul, the waste that can be managed through waste bank program in Sleman Regency reaches 78,966.4 $\mathrm{kg} /$ month and 49,873,5 $\mathrm{kg} /$ month in Bantul Regency.

The percentage of waste management services in the study area may increase (Fig. 1), because the service is also done by the waste bank. By connecting the potential waste of each region, the waste entering the landfill, the current percentage of services, and the amount of waste that can be managed by the waste bank, it can be calculated the percentage of new level of services with the integration of the waste bank system with a formal management system conducted by the relevant institutions.

The percentage of waste services has increased after being integrated with the waste bank in waste management. The integration pattern becomes important to improve the service to the community so that $100 \%$ service access can be achieved immediately. 
Table 2. Integration of percentage of waste management services between formal and informal sector (waste bank) in the study area

\begin{tabular}{|l|c|c|c|}
\hline $\begin{array}{c}\text { City/ } \\
\text { Regency }\end{array}$ & $\begin{array}{c}\text { Waste } \\
\text { Potential } \\
\text { (tons/ } \\
\text { month) }\end{array}$ & $\begin{array}{c}\text { Landfill } \\
\text { Entering } \\
\text { Waste } \\
\text { (tons/ } \\
\text { month) }\end{array}$ & $\begin{array}{c}\text { Level of } \\
\text { Service } \\
\text { (\%) }\end{array}$ \\
\hline Yogyakarta & 8.558 & 7.023 & 85 \\
\hline Sleman & 24.398 & 4.488 & 30,71 \\
\hline Bantul & 20.408 & 1.706 & 7,49 \\
\hline Regency & $\begin{array}{c}\text { Waste } \\
\text { Potential in } \\
\text { Waste Bank }\end{array}$ & $\begin{array}{c}\text { Level of } \\
\text { Service in } \\
\text { Waste } \\
\text { Banth) }\end{array}$ & $\begin{array}{c}\text { New } \\
\text { Level of } \\
\text { Service } \\
\text { (\%) }\end{array}$ \\
\hline Yogyakarta & 899,8 & 10,5 & 95,5 \\
\hline Sleman & 79,0 & 0,3 & 31,0 \\
\hline Bantul & 49,9 & 0,2 & 7,7 \\
\hline
\end{tabular}

\section{Conclusion}

a. The uneven level of formal sector waste management services in the study area is caused by factors such as limited infrastructure, human resources, and funding.

b. A significant increase in community participation in various community-based waste management activities until 2017 amounted to 792 locations and 492 of it as the waste bank $(62.5 \%)$.

c. The waste bank has an average customer number of 43 customers, with the dominance of paper and plastic waste that is put into the waste bank. As per waste bank can manage as much as $2,078,064 \mathrm{~kg}$ of waste/month.

d. The number of the waste bank in Yogyakarta City 433 units can manage waste up to $899,801,8$ $\mathrm{kg} / \mathrm{month}$, Sleman Regency 34 waste bank units (78.966,4 kg/month) and Bantul Regency 24 waste bank units (49.873,5 kg/month).

e. Integration of percentage of waste management services increased in Yogyakarta from $85 \%$ to $95,5 \%$, Sleman Regency from 30,71 to $31 \%$, and Bantul Regency from 7.49 to $7.7 \%$.

\section{References}

1. Asisten Deputi Pengelolaan Sampah, Buku Profil Bank Sampah Indonesia 2012. Kementerian Negara Lingkungan Hidup, Jakarta (2012)

2. Deputi Bagian PPL, Statistik Persampahan Domestik Indonesia Tahun 2008. Kementerian Negara Lingkungan Hidup, Jakarta (2008)

3. Ditjen Pengelolaan Sampah dan B3, Kebijakan Nasional tentang Bank Sampah Induk. Disampaikan di Rakornas Pengelolaan Sampah dan Raker Pengelolaan Sampah, Limbah dan B3. Kementerian
Lingkungan Hidup dan Kehutanan. Palembang (2017)

4. H.P. Putra, E. Damanhuri, A. Marzuko, Landfill Mining Prospect in Indonesia. Proceeding of $3^{\text {rd }}$ Symposium of the Asian Regional Branch of International Waste Working Group. Seoul National University. Seoul (2017)

5. H.P. Putra, S. E. Saputra, Bank Sampah sebagai Alternatif Model Pengelolaan Sampah Berbasis Masyarakat. Proceeding National Conference II Forum Wahana Teknologi, 253-263 (2015)

6. S. Raharjo, T. Matsumoto, T. Ihsan, I. Rachman, Community-based solid waste bank program for municipal solid waste management improvement in Indonesia:a case study of Padang city. Journal of Material Cycles and Waste Management, DOI 10.1007/s10163-015-0401-z (2015)

7. H.P. Putra, E. Damanhuri, Performance and Operational of Landfill Piyungan as The Regional Landfill in Yogyakarta Special Region, Indonesia. Proceeding of The 9th Asia-Pacific Landfill Symposium. University of Hongkong. Hongkong (2016)

8. BPS Yogyakarta. Data Jumlah Penduduk Propinsi Daerah Istimewa Yogyakarta (2016)

9. S.A. Ahmed, M. Ali, Partnerships for solid waste management in developing countries: linking theories to realities. Habitat International, 28, 467479 (2004)

10. E. Damanhuri, A future prospect of municipal solid waste management in Indonesia. Keynote Lecture 5th Asian-Pasific Landfill Symposium di Sapporo, Jepang (2008)

11. Dirjen Cipta Karya, Buku pedoman penyelenggaraan pembangunan bidang Cipta Karya, Volume 4 : Pengembangan pengelolaan persampahan, Kementeriaan Pekerjaan Umum dan Perumahan Rakyat, Indonesia (2015)

12. C. Meidiana, T. Gamse, Development of Waste Management Practices in Indonesia. European Journal of Scientific Research, Vol.40 No.2, 199-210 (2010)

13. W.L. Filho, L. Brandli, H. Moora, Kruopiene, A. Stenmarck, Benchmarking approaches and methods in the field of urban waste management. Journal of Cleaner Production, 112, 4377-4386 (2016)

14. BLH DIY, Rencana Aksi Sampah Daerah DIY. Yogyakarta, Indonesia (2014)

15. S.A. Mulasari, A.H. Husodo, N. Muhadjir, Kebijakan pemerintah dalam pengelolaan sampah domestik. Kesmas, Jurnal Kesehatan Masyarakat Nasional, Vol 8 No 8, 404-410 (2014)

16. Merti Boemi Lestari, Profil jejaring pengelola sampah mandiri Provinsi DIY. Badan Lingkungan Hidup Propinsi DIY, Yogyakarta (2011)

17. BLH DIY, Data pengelola sampah mandiri di Propinsi Yogyakarta Tahun 2015. Yogyakarta (2015) 
18. Faizah, Pengelolaan sampah rumah tangga berbasis masyarakat : studi kasus di Kota Yogyakarta. Tesis Magister Ilmu Lingkungan. Universitas Diponegoro. Semarang (2008)

19. M. Medina, Scavenger cooperatives in Asia and Latin America. Resources, Conservation and Recycling, 31, 51-69(2000)

20. CA. Velis, D.C. Wilson, O. Rocca, S.R. Smith, A. Mavropoulos, C.R. Cheeseman, An analytical framework and tool ('InteRa') for integrating the informal recycling sector in waste and resource management systems in developing countries. Waste Management and Research, 30, 43-66 (2012)

21. F. Fei, L. Qu, Z. Wen, Y. Xue, H. Zhang, (2016). How to integrate the informal recycling system into municipal solid waste management in developing countries: Based on a China's case in Suzhou urban area. Resources, Conservation and Recycling, 110, 74-86 (2016)

22. E Sembiring, V. Nitivattananon, Sustainable solid waste management toward an inclusive society: Integration of the informal sector. Resources, Conservation and Recycling Journal, 54, 802-809 (2010)

23. J.G. Paul, J. Arce-Jaque, N. Ravena, S.P. Villamor, Integration of the informal sector into municipal solid waste management in the Philippines - What does it need?, Waste Management Journal, 32, 2018-2028 (2012) 